\title{
Jean-Martin Charcot, father of modern neurology: an homage 120 years after his death
}

\author{
Jean-Martin Charcot, pai da neurologia moderna: homenagem, 120 anos após sua morte \\ Marleide da Mota Gomes ${ }^{1}$, Eliasz Engelhardt²
}

\begin{abstract}
Jean-Martin Charcot was a pioneer in a variety of subjects, including nervous system diseases; anatomy; physiology; pathology; and diseases of ageing, joints, and lungs. His medical achievements were mainly based on his anatomopathological proficiency, his observation, and his personal thoroughness that favored the delineation of the nosology of the main neurological diseases, including multiple sclerosis, amyotrophic lateral sclerosis, Parkinson's disease, peroneal muscular atrophy, and hysteria/epilepsy. The link of this anatomoclinical method with iconographic representations and theatrical lessons, and the rich bibliographical documentations, carried out in a crowded diseased people barn - Salpetrière hospital were the basis of his achievements, which are still discussed 120 years after his death.
\end{abstract}

Keywords: Charcot, neurology, multiple sclerosis, amyotrophic lateral sclerosis, Parkinson’s disease, peroneal muscular atrophy, hysteria, epilepsy.

\section{RESUMO}

Charcot foi um pioneiro em uma variedade de assuntos, incluindo doenças, anatomia, fisiologia e patologia do sistema nervoso, além de doenças do envelhecimento, das articulações e dos pulmões. Seu desempenho médico foi baseado principalmente em sua expertise anatomopatológica aliada a sua observação e rigor pessoal, o que favoreceu a delimitação da nosologia das principais doenças neurológicas. Isto inclui a esclerose múltipla, esclerose lateral amiotrófica, doença de Parkinson, atrofia muscular peroneal e histeria/epilepsia. A ligação deste método anátomo-clínico com representações iconográficas e sessões teatrais, e as documentações ricas bibliográficas, realizadas em um celeiro de pessoas doentes - Hospital da Salpetrière, lançou sua personalidade e conquistas até hoje, 120 anos após sua morte.

Palavras-chave: Charcot, neurologia, esclerose múltipla, esclerose lateral amiotrófica, doença de Parkinson, atrofia muscular peroneal, histeria, epilepsia.

Jean-Martin Charcot (Figure 1) died 120 years ago at the age of 67 , from a heart attack and pulmonary edema that was preceded by chronic back ailment, angina pectoris, and possibly parkinsonism ${ }^{1-3}$. By the time of his death, the nosology of the main neurological diseases had already been classified, mainly thanks to his work.

\section{SOCIALASPECTS}

Charcot was the son of a carriage-maker ${ }^{1,4}$. He married a wealthy widow and had two children, Jeanne and Jean
Baptiste who became a doctor and a famous polar explorer ${ }^{2,4}$. Charcot had a refined artistic taste in the Paris Belle Époque, and on vacations he traveled to enjoy museums and art collections ${ }^{1}$. Charcot also had a great ability to draw, and he was fond of music, Shakespeare, and the classics ${ }^{3,5}$. His voice was distinct but low, his manner showed dignity, and he was somewhat aloof, but among friends he was very amiable ${ }^{1}$. Beyond his medical obligations, Charcot had close links with political circles, sustaining progressive and anticlerical ideas ${ }^{6}$. Although he was indifferent to the payment of fees by his patients and money issues, he was highly appreciative of honorary distinctions ${ }^{2}$.

\footnotetext{
${ }^{1}$ Neurologist, Associate Professor, Institute of Neurology Deolindo Couto, School of Medicine, Federal University of Rio de Janeiro (UFRJ), Rio de Janeiro RJ, Brazil; ${ }^{2}$ Neurologist, Full Professor (retired), Cognitive and Behavioral Neurology Unit, Institute of Neurology, Institute of Psychiatry, Federal University of Rio de Janeiro (UFRJ), Rio de Janeiro RJ, Brazil.

Correspondence: Marleide da Mota Gomes; Instituto de Neurologia Deolindo Couto, UFRJ; Av. Venceslau Braz 95; 22290-140 Rio de Janeiro RJ - Brasil; E-mail: mmotagomes@acd.ufr.br

Conflict of interest: There is no conflict of interest to declare.

Received 17 March 2013; Received in final form 03 May 2013; Accepted 10 May 2013.
} 


\section{CAREER}

Charcot became a hospital intern in (1848) and was appointed chef de clinique (1853) after defending his thesis on gout and chronic rheumatism ${ }^{4,7}$. He became médecin des hôpitaux de Paris (1856) ${ }^{4,7}$, and Guillaume Duchenne was described by Charcot as his master in Neurology ${ }^{2}$. Charcot became Professeur agrégé (1860), and in 1862, he was appointed senior physician at the Salpêtrière, which was built in the $16^{\text {th }}$ century to store gunpowder but was converted into a public hospital in the $17^{\text {th }}$ century ${ }^{1,3,4}$. At the time of Charcot, Salpêtrière Hospital was an enormous asylum holding a population of about 5,000 patients, largely old women with several chronic diseases, mostly of the nervous system, who had a high mortality rate ${ }^{1,3}$. Charcot's work was temporarily interrupted during the Franco-Prussian war of 1870$1871^{4,7}$. He succeeded his friend Alfred Vulpian as a professor of pathological anatomy at the School of Medicine at the University of Paris from 1872-82, a critical turning point in his career ${ }^{1,6}$. In 1882, he was appointed as the first chair of Neurology at the same School ${ }^{1,6}$.

\section{MEDICAL ACHIEVEMENTS}

Charcot's research was established on the anatomoclinical method. This knowledge facilitated his studies on localizing functions in the brain and spinal cord by means of clinical correlations of post-mortem findings ${ }^{1}$. He was a man with method and the ability to make observations. His drawings demonstrate the accuracy of his semiology - they contain everything that he so thoroughly and analytically described, placing the relevant and characteristic aspects of each disease within it ${ }^{1,2,5}$. To provide examples in his classes, conferences, and writings he used photographs and drawings that were many made by himself or his students ${ }^{3,5,8}$. In 1866 ,

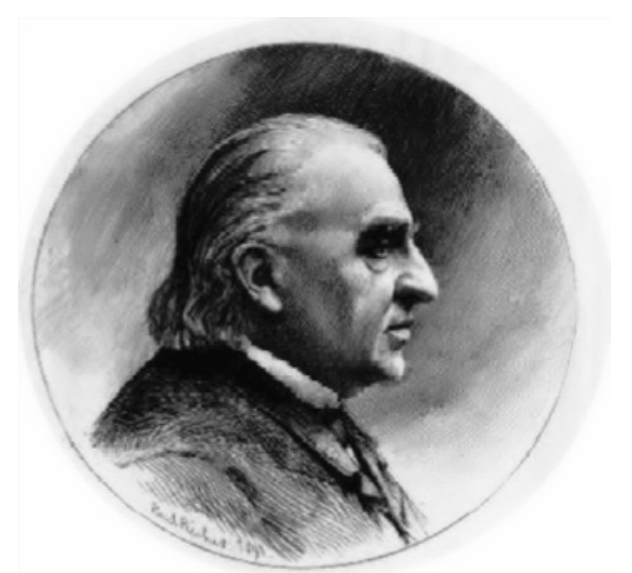

Figure 1. Jean-Martin Charcot (Paris, 29 November 1825 Montsauche-les-Settons, 16 August 1893) (source: Oeuvres complètes by Charcot $^{7}$ ). he inaugurated his innovative clinical lectures, the first series was on diseases in the elderly ${ }^{2,3,4}$. His worldwide notability came from the weekly Tuesday morning sessions, where he described clinical cases he had examined in the presence of the audience (André Brouillet's famous 1887 painting gave its atmosphere) and Friday lessons, where he presented didactic lectures prepared in advance ${ }^{5,6}$.

When Charcot moved to the Boulevard St. Germain, he hosted weekly Tuesday soirées that gathered varied personalities, such as the Emperor of Brazil, who was also one of his clients ${ }^{4,8}$. Charcot diagnosed the emperor with mental stress (surmenage physique et intellectuel), diabetic neuropathy, and a cerebral vascular lesion (probably a stroke), which he differentiated from other vascular lesions elsewhere ${ }^{8}$.

Some of his outstanding students were Paul Richer, Georges Fulgence Raymond, Edouard Brissaud, Pierre Marie, Joseph Babinski, Georges Gilles de la Tourette, and many others, including, Freud and Bechterew ${ }^{4,6}$. He had great ability to attract students from all around the world ${ }^{2}$ a gift inherited, by Pierre Marie and Babinski, masters of Brazilian neurology pioneers ${ }^{9}$. Charcot's vast medical experience was remarkable, and this was demonstrated in his way of teaching and in his capacity to disseminate his vast knowledge through papers and books with his students support. These themes were mainly related to nervous diseases and "neurological like disorders," such as hysteria ${ }^{10}$ (Box).

Charcot made the first correlations between the clinical features of multiple sclerosis and the pathological changes found post-mortem. Charcot called the disease la sclérose en plaques for the first time in $1868^{6,7}$. He also named paralysis agitans (shaking palsy) after James Parkinson (Parkinson's disease) (1872), and distinguished bradykinesia from rigidity as a unique cardinal feature of the illness ${ }^{3}$ (Figure 2). His observations on autopsy allowed him to differentiate patients with "intention tremor" in life due to sclerotic plaques in

\footnotetext{
Box. Content of the Charcot's series entitled Oeuvres complètes (1886-1892)7

- The masterwork consists of five (I-IV, IX) volumes on Lessons on Neurological themes, 1-3, named Leçons sur les Maladies du Système Nerveux.

- They were collected and published by Bourneville (I-II), Babinski, Bernard, Fere, Guinon Marie, Gilles de la Tourette, and Brissaud (III).

- They included lessons on: (I) Trophic troubles, paralysis agitans, and multiple sclerosis, hysteria; (II) Locomotor ataxia anomalies, slow compression of the spinal cord, amiotrofies amyotrophies, spasmodic dorsalis tabes, urinary paraplegia, Menière vertigo, post-hemiplegic hemichorea, partial syphilitic epilepsy; (III) The great majority was about hysteria, as well as progressive muscular atrophy, contractures, aphasia, verbal blindness, and rhythmic chorea; (IV) Locations of brain and spinal cord disease; (IX) Hemorrhage and softening of the brain, metallotherapy and hypnosis, electrotherapy.

- Other volumes are on lung diseases, vascular system diseases, liver, biliary tract and kidney diseases, elderly diseases, gout and rheumatism, infectious and skin diseases, and hydatid cysts.
} 


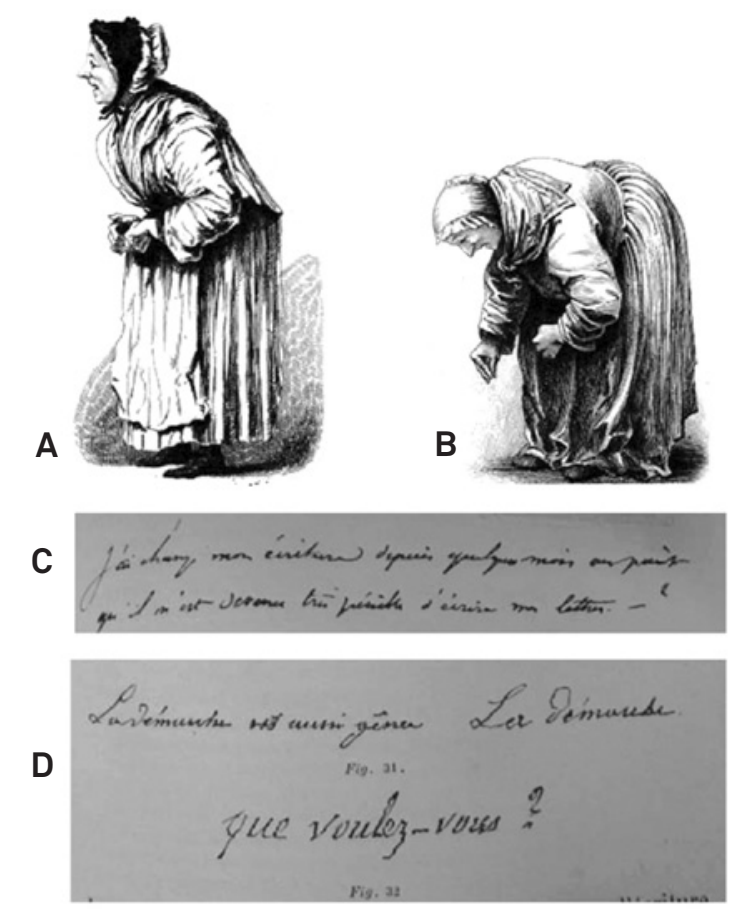

Figure 2. Parkinson's disease: A-B, postures; C-D, micrograph and tremor (source: Oeuvres complètes by Charcot $^{7}$ ).

the brain (which he termed "multiple sclerosis") from those that presented with "rest tremor," without apparent (at the time) brain pathology, with a clinical diagnosis consistent with Parkinson disease. He described and diagnosed, in 1869, the first cases of "amyotrophic lateral sclerosis" as a specific neurological disease associated with a distinct pathology ("Charcot disease") ${ }^{6,7}$. Charcot and his assistant, Pierre Marie, also described "peroneal muscular atrophy" (1886), later named Charcot-Marie-Tooth disease, and Charcot firstly classified it as a neuropathy rather than a myopathy ${ }^{7}$. Charcot's other significant accomplishments include the description of the vascular supply of the brain, the differentiation of several types of tremor (found in Parkinson's disease, multiple sclerosis, and patients with postural tremor), and distinguishing hysteria from epilepsy ${ }^{3,6,7}$. He was also the first to describe arthropathies in patients with tabes dorsalis or Charcot joint $(1869)^{2,4}$.

Charcot's attempts to apply his anatomoclinical method to the difficult neurological diagnosis of the multiplex semiology of hysteria led him to experiments, such as hypnosis, and conclusions that attracted disapproval from many colleagues. However, these approaches helped to separate hysteria from epilepsy, insanity, and "organic disorders," and also stimulated several of Charcot's disciples to follow the psychiatry field ${ }^{6}$.

\section{CONCLUSION}

Charcot enlarged the body of knowledge and opened new doors in the field of neurology and associated domains by means of a meticulous style as embellished in the Paris' Belle Époque. This made him one of the most luminous physicians of all time.

\section{References}

1. Garrison FH. The Charcot centenary. Bull N Y Acad Med 1925;1:365-369.

2. Commemoration at the Royal Society of Medicine. The Charcot centenary. Br Med J 1925;1:1134-1135.

3. Goetz CG. Jean-Martin Charcot and the aging brain. Arch Neurol 2002;59:1821-1824.

4. Bonduelle M. Charcot. Dates. Légendes et réalité. Histoire des sciences médicales 1994;28:289-295.

5. Salomone G, Arnone R. Charcot and his drawings: images from “les leçons du mardi à la Salpêtrière 1887-1888." Ital J Neurol Sci 1994;15:203-211.

6. Broussolle E, Poirier J, Clarac F, Barbara JG. Figures and institutions of the neurological sciences in Paris from 1800 to 1950. Part III: Neurology. Rev Neurol (Paris) 2012;168:301-320.

7. Kumar DR, Aslinia F, Yale SH, Mazza JJ. Jean-Martin Charcot: The father of neurology. Clin Med Res 2011;9:46-49.

8. Gomes MM. The decline of Dom Pedro Il's empire and health: neurophatogenic implications. Arq Neuropsiquiatr 2007;65:1260-1265.

9. Gomes MM, Engelhardt E. French School of Neurology in the $19^{\text {th }}$ and first half of the $20^{\text {th }}$ century and its influence in Brazil. Arq Neuropsiquiatr 2013;71:818-821.

10. CharcotJM. Oeuvres complètes. 9 volumes. Paris: Bureaux de Progrés Médical [and other publishers], 1886-1890. 